\title{
Aktivitas Antioksidan Wedelolakton dari Fraksi Etil Asetat daun Urang Aring (Eclipta alba (L.) Hassk)
}

\section{Antioxidant Activity of Wedelolakton from Urang Aring (Eclipta alba (L.) Hassk) Ethyl Acetate Fraction}

\author{
Trisna Yuliana \\ Jurusan Kimia, FMIPA, Universitas Jenderal Achmad Yani, Jl. Ters Jend. Soedirman PO Box 148, Cimahi, \\ 40526, Indonesia.
}

Email:trisna.yuliana@lecture.unjani.ac.id; trisyuliana@gmail.com

Received: August 2017; Revised: September 2017; Accepted: October 2017; Available Online: November 2017

\begin{abstract}
Abstrak
Urang aring (Eclipta alba (L.) Hassk secara tradisional telah banyak digunakan sebagai tumbuhan obat. Daun urang-aring banyak digunakan untuk mengobati sesak nafas, sakit kepala, sakit gigi, bronkhitis, gangguan haid, dan sebagai penyubur rambut. Ekstrak dari tumbuhan urang aring dari berbagai jenis pelarut menunjukkan beberapa aktivitas seperti antioksidan dan antibakteri. Dalam penelitian ini telah dikaji uji aktivitas antioksidan dari wedelolakton murni hasil isolasi dari daun urang aring. Proses isolasi dilakukan secara konvensional menggunakan cara maserasi, partisi, dan kromatografi kolom serta dikarakterisasi dengan menggunakan KLT, LCMS dan spektroskopi UV-Vis dan NMR. Hasil percobaan menunjukkan, isolat wedelolakton mempunyai aktivitas antioksidan $\mathrm{IC}_{50}$ pada konsentrasi $(5.6 \pm 0.5) \mathrm{ug} / \mathrm{mL}$ didampingi dengan asam askorbat sebagai kontrol positif.
\end{abstract}

Kata kunci: Eclipta alba L., wedelolaktone, uji aktivitas anti oksidan, DPPH.

\begin{abstract}
Urang aring plants (Eclipta alba (L.)) Hassk has been traditionally used as a medicinal plant. Leaf of urangaring widely used to treat asphyxia, headache, toothache, bronchitis, menstrual disorders, and as a fertilizer hair. Extracts from Eclipta alba (L.) Hass plants from various types of solvents show some activities such as antioxidants and antibacterials. In this research has been studied antioxidant activity test from wedelolactone isolate resulted from Eclipta alba (L.) Hass leaves. The isolation process is carried out conventionally by means of maceration, partition, and column chromatography and characterized by TLC, LCMS and UV-Vis and NMR spectroscopy. The results showed that wedelolactone isolate had antioxidant activity of $\mathrm{IC}_{50}$ at concentration $(5.6 \pm 0.5) \mathrm{ppm}$.
\end{abstract}

Keywords: Eclipta alba L., wedelolactone, antioxidant activity test, DPPH assay.

DOI: http://dx.doi.org/10.15408/jkv.v3i2.6087

\section{PENDAHULUAN}

Urang-aring (Eclipta alba L.) merupakan tanaman obat herbal yang secara tradisional, seluruh bagian tanaman, baik segar maupun kering dapat digunakan untuk menyembuhkan berbagai macam penyakit.
Daun urang-aring banyak digunakan untuk mengobati sesak nafas, sakit kepala, sakit gigi, bronkhitis, gangguan haid, dan sebagai penyubur rambut (Unnikhrisnan et al., 2007). Tepung keseluruhan tanaman urang-aring dapat digunakan untuk mengobati gangguan hati (Sagrawat dan Khan Yaseen, 2007). 
Sebagai kosmetika telah diproduksi menjadi minyak rambut urang-aring dan shampo urangaring yang sudah banyak dikenal masyarakat Indonesia.Kajian aktivitas ekstrak dari berbagai bagian tumbuhan urang aring ini telah beberapa kali dilakukan terutama aktivitas antioksidan.

Unnikhrisnanet al., (2007), Majumdar (2008), Prabu et al., (2011), Gani dan Nalini Devi (2015), Chandan et al., (2012) dan Patel et al., (2016) melakukan kajian aktivitas antioksidan dari ekstrak metanol atau ekstrak hidroksi alkohol tanaman urang aring dengan menggunakan metode 1,1-diphenyl-2picrylhydrazil (DPPH). Panjang gelombang yang digunakan berkisar $516 \mathrm{~nm}$ hingga 520 $\mathrm{nm}$. Persen inhibisi yang didapatkan berkisar $19.25 \mu \mathrm{g} / \mathrm{mL}$ hingga $175 \mu \mathrm{g} / \mathrm{mL}$. Metode DPPHpun digunakan oleh Khartikumar et al., (2007) untuk menguji aktivitas antioksidan hanya saja uji tersebut dilakukan terhadap ekstrak etanol. Persen inhibisi $\left(\mathrm{IC}_{50}\right)$ yang diperolehnya pada konsentrasi $500 \mu \mathrm{g} / \mathrm{mL}$.

Pada kajian ini dipaparkan uji aktivitas antioksidan terhadap wedelolakton hasil isolasi dari daun urang aring yang diperoleh dari fraksi etil asetat menggunakan metode DPPH

\section{METODE PENELITIAN}

\section{Alat dan Bahan}

Peralatan yang digunakan di Laboratorium Kimia seperti peralatan gelas, rotary evaporator, spektrofotometer UV-Vis, seperangkat peralatan spektrometri NMR 9.4 Tesla ( ${ }^{1} \mathrm{H}$ pada $400 \mathrm{MHz}$ dan ${ }^{13} \mathrm{C}$ pada 100 $\mathrm{MHz}$ ) di Graduate School of Life and Environment Sciences, Osaka Prefecture University, Jepang. dan LC-MS di Pusat Penelitian Kimia - LIPI Serpong.

Bahan tanaman yang digunakan dalam penelitian ini adalah bagian daun dan tangkai yang melekat pada daun Eclipta alba (L.) Hassk. yang telah dikeringkan. Tanaman ini diambil dari kebun Manoko, diidentifikasi oleh staf Balitro pada bulan Agustus 2010 dan spesimen dengan nomor koleksi 126 tersimpan di kebun percobaan Manoko Balitro Lembang. Standar Wedelolakton (E. Merck) yang digunakan sebagai pemandu (acuan). Berbagai jenis pelarut organik teknis yang didestilasi ulang seperti $n$-heksan, etil asetat, metanol, aseton dan larutan DPPH. Silika gel $\mathrm{GF}_{254}$ untuk kromatografi lapis tipis (KLT) dan silika gel (230-400 mesh) untuk kromatografi kolom terbuka, pereaksi penampak noda besi(III) klorida dalam etanol, air suling, asam asetat, toluen, aseton, asam format dan standar asam askorbat (E. Merck) sebagai pembanding.

\section{Ekstraksi dan Isolasi}

Sebanyak 1 (satu) kg serbuk daun dan tangkai daun urang aring (Eclipta alba $L$. Hassk) dimaserasi dengan $10 \mathrm{~L}$ metanol tiga kali berturutan masing-masing selama 24 jam. Gabungan ekstrak metanol hasil tiga kali ulangan maserasi dievaporasi pada suhu $40^{\circ} \mathrm{C}$. Ekstrak metanol pekat (136 g) yang diperoleh kemudian dilarutkan dengan $500 \mathrm{~mL}$ air dan difraksinasi berulang (dipartisi secara ekstrasi cair-cairberturut turut) dengan $n$-heksan dan etil asetat. Fraksi padat etil asetat $(2.78 \mathrm{~g})$ dilarutkan dalam aseton dan diimpregnasi (impregnate) dengan silika gel $(2 \times 2.78 \mathrm{~g})$. Dilakukan dengan cara menambahkan tetes demi tetes larutan fraksi etil asetat dalam aseton di atas silika gel sambil di aduk secara merata sampai kering.

Selanjutnya, dilakukan proses fraksinasi menggunakan teknik kromatografi kolom dielusi secara gradien menggunakan campuran [ $n$-heksan:etil asetat:metanol (10\%)] menjadi 21 fraksi (A1-A21). Eluat diidentifikasi menggunakan teknik KLT dengan panduan standar wedelolakton dan dipantau dengan larutan penampak noda. Ekstrak teridentifikasi positif $(0.86 \mathrm{~g})$ kemudian dimurnikan kembali dengan teknik kromatografi kolom dan dielusi menggunakan eluen campuran $n$ heksan:aseton:metanol. Fraksi (B) yang menunjukkan hasil positif untuk wedelolakton diuapkan dan dihasikan padatan $(612 \mathrm{mg})$. Selanjutnya ditambahkan aseton sedikit demi sedikit kedalamnya. Padatan berwarna putih $(55 \mathrm{mg})$ dan cairan yang terbentuk kemudian diuji dengan teknik KLT menggunakan fasa gerak toluen:aseton:asam format (11:6:1) menghasilkan noda tunggal, memberi informasi bahwa senyawa telah murni. Senyawa tersebut kemudian dikarakterisasi dan hasilnya dibandingkan terhadap referensi (Yuliana, 2013)

\section{Penetapan Aktivitas Antioksidan}

Penetapan radikal bebas menggunakan metode DPPH yang mengacu pada Dudonne yang dimodifikasi. Wedelolakton hasil isolasi divariasikan konsentrasinya $0.5 ; 1 ; 2 ; 4$ dan 8 $\mathrm{ug} / \mathrm{mL}$ dalam metanol. Sebanyak $4 \mathrm{~mL}$ setiap 
larutan uji yang dibuat ditambahkan $1 \mathrm{~mL}$ larutan DPPH $4 \times 10^{-4} \mathrm{M}$ dalam metanol. Setiap campuran kemudian didiamkan pada suhu kamar selama 30 menit. Penurunan absorban larutan sampel $\left(\mathrm{A}_{\mathrm{s}}\right)$ dibaca pada $\lambda 515 \mathrm{~nm}$. Sebagai blanko digunakan $1 \mathrm{~mL}$ larutan metanol dalam larutan DPPH dan diukur serapannya $\left(A_{b}\right)$. Percobaan dilakukan pengulangan sebanyak triplo. Sebagai pembanding dilakukan hal yang sama terhadap lalrutan asam askorbat. Aktivitas antioksidan dihitung menggunakan formula:

$$
\text { \% inhibisi }=\left[\left(A_{b}-A_{s}\right) / A_{b}\right] \times 100
$$

Dimana: $A_{b}=$ serapan blanko sampel; dan $A_{s}=$ serapan sampel isolat wedelolakton.

\section{HASIL DAN PEMBAHASAN}

\section{Karakterisasi isolat}

Padatan sebanyak $55 \mathrm{mg}$ yang terbentuk saat proses isolasi diuji dengan KLT menggunakan fasa gerak toluen:aseton:asam format (11:6:1) menunjukkan satu noda (Rf 0,58) serupa dengan $\mathrm{Rf}$ standar wedelolakton.Hasil pemindaian panjang gelombang maksimum menggunakan spektroskopi UV-Vis menunjukkan panjang gelombang maksimum senyawa wedelolakton hasil isolasi adalah $350 \mathrm{~nm}$ sesuai dengan yang dilaporkan oleh Pallavi dan Mishra (2007) untuk penetapan kandungan wedelolakton dengan menggunakan metode spektrofotometri UV-Vis.

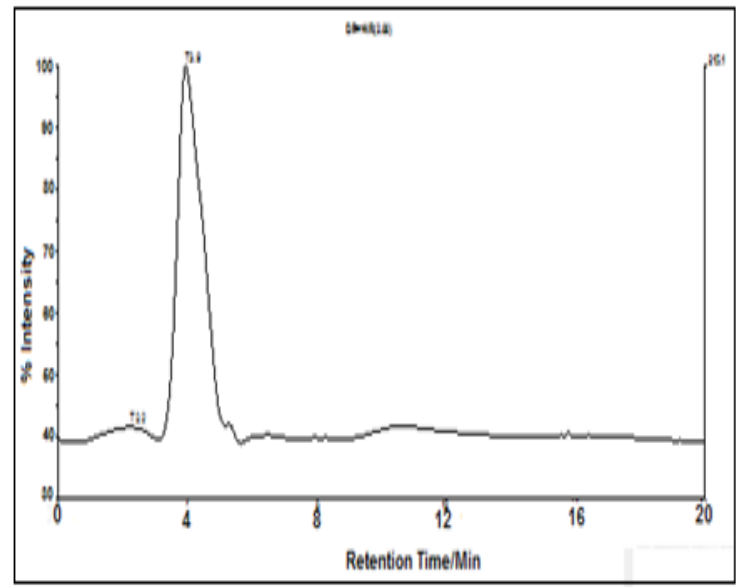

Gambar 1. Profil kromatogram dari isolat wedelolakton
Tabel 1. Luas puncak hasil pengukuran isolat dengan LC-MS

\begin{tabular}{ccc}
\hline No & $\begin{array}{c}\text { Waktu retensi } \\
\text { (menit) }\end{array}$ & Luas puncak \\
\hline 1 & 2.25 & 167.43 \\
2 & 3.94 & 2469.58 \\
\hline
\end{tabular}

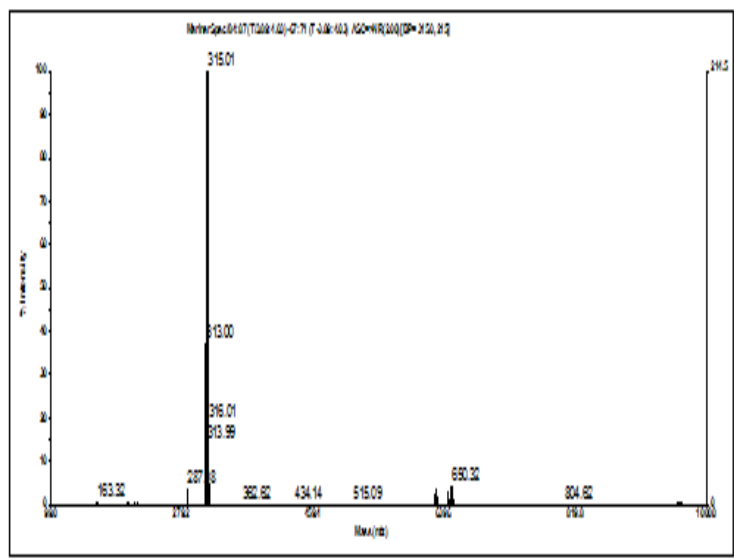

Gambar 2. Profil spektrum massa isolat wedelolakton hasil isolasi pada waktu retensi $\left(t_{R}\right) 3.9$ menit

Tabel 2. Ringkasan hasil pengukuran NMR isolat

\begin{tabular}{|c|c|c|c|c|c|c|}
\hline $\begin{array}{l}\text { Posisi } \\
\text { karbon }\end{array}$ & $\delta_{\mathrm{C}}$ & $* \delta_{\mathrm{C}}$ & $* * \delta_{\mathrm{C}}$ & $\delta_{\mathrm{H}}$ & $* \delta_{\mathrm{H}}$ & $* * \delta_{\mathrm{H}}$ \\
\hline 1 & 155,8 & 154,3 & 155,2 & - & - & \\
\hline 2 & 102,5 & 101,6 & 102,2 & - & - & \\
\hline 3 & 163,1 & 162,3 & 162,7 & - & - & \\
\hline 4 & 105,4 & 104,1 & 104,8 & - & - & \\
\hline 5 & 158,7 & 157,5 & 157,8 & - & - & $\begin{array}{c}10,56(\mathrm{br} \\
\mathrm{s}, 1 \mathrm{H})\end{array}$ \\
\hline 6 & 94,1 & 92,7 & 93 & $\begin{array}{c}6,44(\mathrm{~d}, \\
J=2,4 \mathrm{~Hz}, \\
1 \mathrm{H})\end{array}$ & $\begin{array}{c}6,55(\mathrm{~d}, \\
J=2,4 \mathrm{~Hz}, \\
1 \mathrm{H})\end{array}$ & $\begin{array}{c}6,51(\mathrm{~s} \\
1 \mathrm{H}) \\
\end{array}$ \\
\hline 7 & 159,8 & 158,9 & 159,4 & - & - & \\
\hline 8 & 99 & 97,6 & 98,2 & $\begin{array}{c}6,61(\mathrm{~d}, \\
J=2 \mathrm{~Hz} \\
1 \mathrm{H})\end{array}$ & $\begin{array}{c}6,58 \\
(\mathrm{~d}, J=2,1 \\
\mathrm{Hz}, 1 \mathrm{H})\end{array}$ & $\begin{array}{c}6,53(\mathrm{~s} \\
1 \mathrm{H}) \\
\end{array}$ \\
\hline 9 & 156,2 & 155,2 & 155,8 & & & \\
\hline 10 & 99,8 & 97,8 & 98,5 & $\begin{array}{c}7,22(\mathrm{~s} \\
1 \mathrm{H})\end{array}$ & $\begin{array}{c}7,41(\mathrm{~s} \\
1 \mathrm{H})\end{array}$ & $\begin{array}{c}7,37(\mathrm{~s} \\
1 \mathrm{H}) \\
\end{array}$ \\
\hline 11 & 145,2 & 143,4 & 144,3 & - & - & $\begin{array}{c}8,81(\mathrm{br} \\
\mathrm{s}, 1 \mathrm{H}) \\
\end{array}$ \\
\hline 12 & 146,3 & 144,6 & 145,5 & - & - & $\begin{array}{c}8,85(\mathrm{br} \\
\mathrm{s}, 1 \mathrm{H}) \\
\end{array}$ \\
\hline 13 & 97,6 & 96,4 & 97 & $\begin{array}{c}7,15(\mathrm{~s} \\
1 \mathrm{H})\end{array}$ & $\begin{array}{c}7,22(\mathrm{~s} \\
1 \mathrm{H})\end{array}$ & $\begin{array}{c}7,17(\mathrm{~s} \\
1 \mathrm{H}) \\
\end{array}$ \\
\hline 14 & 149,7 & 149 & 149,5 & - & - & \\
\hline 15 & 114,5 & 114 & 114,5 & - & - & \\
\hline $\mathrm{CH}_{3}-\mathrm{O}$ & 56,6 & 54,8 & 55,3 & $\begin{array}{c}3,80(\mathrm{~s}, \\
3 \mathrm{H})\end{array}$ & $\begin{array}{c}3,89(\mathrm{~s} \\
3 \mathrm{H})\end{array}$ & $\begin{array}{c}3,90(\mathrm{~s} \\
3 \mathrm{H}) \\
\end{array}$ \\
\hline
\end{tabular}

* Li et al., (2003); ** Chang et al., (2008) 
Pengukuran massa molekul relatif isolat wedelolakton dilakukan dengan menggunakan LC-MS. Hasil pengukuran menunjukkkan adanya dua puncak pada waktu retensi 2.2 dan 3.9 menit (Gambar 1) dengan luas puncak masing-masing 167.43 dan 2469.58 seperti yang tertera pada Tabel 1. Pada Gambar 2 terlihat massa yang terukur pada waktu retensi 3.9 yaitu sebesar $315.01\left([\mathrm{M}+\mathrm{H}]^{+}\right)$, atau $[\mathrm{M}]=$ 314.0 yang sesuai dengan $\mathrm{Mr}$ wedelolakton. (Yuliana, 2013).

Struktur wedelolakton dikarakterisasi melalui pengukuran dengan spektroskopi ${ }^{13} \mathrm{C}$ NMR dan ${ }^{1} \mathrm{H}-\mathrm{NMR}$. Data pada tabel 2 merupakan hasil rekapitulasi konfirmasi pengukuran NMR hasil percobaan dan hasil referensi. Dari tabel tersebut terlihat spektrum proton dan karbon isolat berada pada daerah geseran kimia $(\delta)$ yang relatif sama dengan yang dilaporkan oleh Li et al., (2003) dan Chang et al., (2008). Ini menunjukkan bahwa berdasarkan pengukuran ${ }^{1} \mathrm{HNMR}$ dan ${ }^{13} \mathrm{CNMR}$, isolat hasil percobaan merupakan senyawa wedelolakton (Yuliana, 2013).

\section{Aktivitas Antioksidan}

\section{Radikal bebas 1,1-diphenyl,2-} picrylhydrazil (DPPH) adalah radikal bebas yang memiliki sifat paramagnetik oleh karena adanya elektron yang tidak berpasangan. Ketidakhadiran satu elektron inilah yang menyebabkan senyawa tersebut reaktif mencari pasangannya dengan cara menyerang dan mengikat elektron molekul yang berada disekitarnya. Gugus kromofor dan auksokrom pada radikal bebas DPPH dalam metanolberwarna ungu, memberikan serapan pada panjang gelombang $515 \mathrm{~nm}$. Warna DPPH akan berubah menjadi kuning atau hilang seiring dengan penambahan senyawa antioksidan.Hasil dekolorisasi/ penghilangan warna atau penurunan intensitas warna ini setara dengan jumlah elektron yang tertangkap.

Daya hambatisolat wedelolakton terhadapradikal bebas DPPH dapat dilihat pada tabel 3.Daya hambat tersebut tergantung pada konsentrasi seperti yang terlihat pada Gambar 3 dengan nilai koefisien korelasi sebesar (r) 0.9933 .

Berdasarkan persamaan kurva yang diperoleh, maka nilai $\mathrm{IC}_{50}$ isolat wedelolakton beserta dengan rentang ketidakpastiannya melalui perhitungan (Eurachem, 2011) yaitu sebesar $(5.60 \pm 0.45)$ ppm. Jika dibandingkan terhadap aktivitas asam askorbat sebagai acuan maka dapat dilihat isolat wedelolakton memiliki potensi sebagai anti oksidan seperti yang terlihat pada gambar 4 .

Tabel 3. Daya hambat isolat wedelolakton terhadap radikal bebas DPPH

\begin{tabular}{cc}
\hline Perlakuan & Serapan isolat wedelolakton* \\
\hline kontrol & $0.818 \pm 0.002$ \\
$0.5 \mathrm{ppm}$ & $0.782 \pm 0.014$ \\
$1 \mathrm{ppm}$ & $0.736 \pm 0.015$ \\
$2 \mathrm{ppm}$ & $0.631 \pm 0.026$ \\
$4 \mathrm{ppm}$ & $0.489 \pm 0.012$ \\
$8 \mathrm{ppm}$ & $0.263 \pm 0.016$ \\
\hline *sebagai nilai & rerata \pm rentang keyakinan \\
$(\mathrm{n}=3 ; 95 \%)$ &
\end{tabular}

Daya hambat isolat wedelolakton terhadap radikal bebas DPPH

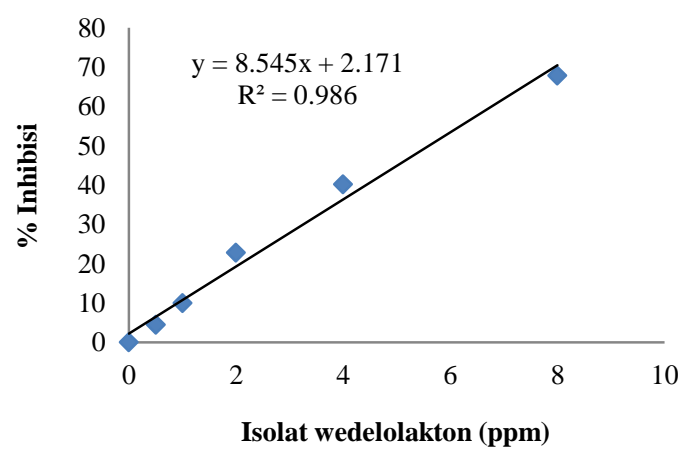

Gambar 3. Aktivitas antioksidan isolat wedelolakton

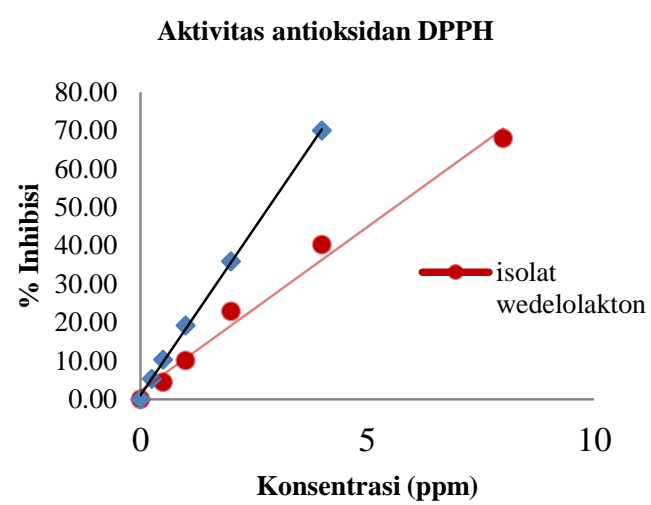

Gambar 4. Aktivitas antioksidan isolat wedelolakton dan asam askorbat 


\section{SIMPULAN}

Hasil kajian ini menunjukkan bahwa wedelolakton hasil isolasi dari daun urang aring menunjukkan aktivitas antioksidan dengan nilai $\mathrm{IC}_{50}$ sebesar $(5.6 \pm 0.5) \mathrm{ppm}$.

\section{UCAPAN TERIMA KASIH}

Penulis mengucapkan terimakasih yang sebesar besarnya kepada Prof. Dr. Muljadji Agma atas koreksi dan bimbingan selama penulisan. Dr. Julia Kantasubrata (PPKimia LIPI), Prof. Dr. Unang Supratman \& Dr. Iwan Hastiawan (UNPAD) serta Prof. Hideo Hayashi, PhD (Graduate School of Life \& Environment Sciences, Osaka Prefecture University Japan) atas dukungan terhadap penelitian.

\section{DAFTAR PUSTAKA}

Chandan S, Umesha S, Balamurugan V. 2012. Antileptospiral, antioxidant and DNA damaging properties of Eclipta alba and Phyllanthus amarus. Open Access Scientific.

Chang CF, Yang LY, Chang SW, Fang YT, \&Lee YJ. 2008. Total synthesis of demethyl wedelolactone and wedelolactone by $\mathrm{Cu}$ mediated/Pd(0)-catalysis and oxidativecyclization, Tetrahedron. 64: 3661-3666.

Dudonne S, Vitrac X, Coutiere P, Woillez M, Merillon JM. 2009. Comparative study of antioxidant properties and total phenolic content of 30 plants extracs of industrial interest using DPPH, ABTS, FRAP, SOD, and ORAC assays. J. Agric. Food Chem. 57: 1768-1774.

Eurachem. 2011. Quantifying uncertainty in analytical measurement. 3rd ed. Eurachem/CITAC GUIDE CG 4.

Gani AMS, Nalini DD. 2015. Antioxidant activity of methanolic extract of Eclipta Prostata (L.) L. International Journal of Phytopharmacy. 5(2): 21-24
Karthikumar S, Vigneswari K, Jegatheesan K. 2007. Screening of antibacterial and antioxidant activities of leaves of Eclipta Prostata (L). Scientific Research and Essay. 2(4): 101-104

Li CC, Xie ZX,Zhang YD, Chen ZH,YangZ. 2003, Total synthesis of wedelolactone. J. Org. Chem. 68: 8500-8504.

Majumdar AS. 2008. Preliminary studies on the antioxidant activity of Tribulus terrestris and Eclipta alba. Pharmacognosy Magazine. 4(13): 102 - 107

Pallavi R, Mishra SH. 2007. Development of a simple and sensitive spectrophotometric method for the simultaneous determination of asiaticoside and wedelolactone in a polyherbal formulation. Pharmacognosy Magazine. 3(9): 47 - 51.

Patel M, Verma R, Srivastav P. 2016. Antioxidant activity of Eclipta alba extract. Journal of Medicinal Plants Studies. 4(5): 92-98.

Prabu K, Shankarlal S, Natarajan E, Sadiq AM. 2011. Antimicrobial and antioxidant activity of methanolic extract of Eclipta alba. Advance in Biological Research. 5(5): 237240.

Sagrawat H, Khan YM. 2007. Immunomodulatory Plants: A Phytopharmacological Review. Pharmacognosy Revie. 1(2): 248 - 260

Unnikhrishnan KP, Anu F,Hashim KM, Balachandran I. 2007. Antioxidant studies and determination of wedelolakton in Eclipta albae. Journal of Plant Sciences. 2(4):459-464

Winarsi H. 2007. Antioksidan alami dan radikal bebas. Yogyakarta: Penerbit Kanisius.

Yuliana T. 2013. Isolasi dan pemurnian wedelolakton dari tumbuhan urang aring (Eclipta alba L. Hassk). Jurnal Kimia Terapan Indonesia. 15(1): 1-7. 